Transubstantiation, the sacrifice of the Mass, the Virgin Birth, the Church and similar subjects; he will find treatments of the Historicity of Jesus, the Mythical Theory, etc., but he will be compelled to organize this material into a consistent whole. He will find no organizing principle in the book.

W. J. McGlothlin.

William McKendree: A Biographical study. By Bishop E. E. Hoss, Methodist Founders' Series. Smith \& Lamar, Nashville, Tenn, 1914. 206 pp. $\$ 1.00$.

The Methodist Church is doing well in publishing this admirable series of brief popular and yet scholarly biographies. It would be a great loss to the forces of the kingdom for the heroic efforts of these founders of Methodism to be forgotten. They are among the treasures of all Christians.

McKendree was one of the most important of the Methodist pioneers. He was American born, a Virginian, with great native ability, deep consecration and burning zeal. It was he who inspired and organized Methodism west of the Alleghenies and made it one of the redeeming forces in this then frontier country. The story is full of intense and inspiring interest. Bishop Hoss has told it well, with sympathetic insight into the condition of those primitive days, with appreciation of the heroic self-sacrifice of those early preachers in their rude surroundings, with fullness of knowledge and good style. Every reader, and especially Methodist, will find this brief biography both interesting and inspiring.

W. J. MoGiothlin.

Contemporary American History, 1877-1913. By Chas. A. Beard, Associate Professor of Political History in Columbia University. The Macmillan Company, New York, 1914, 397 pp. $\$ 1.00$ net.

To write a thoroughly good history of our own times is perhaps impossible. We lack distance and perspective, movements have not had time to work themselves out to legitimate results, prejudices and party passions are too active. Such a history must necessarily confine itself largely to the external progress 
of events. And yet such a book, when the work is well done, is very useful. The date and sequence of events and the circum. stances that made them living realities, rapidly slip from memory. Hence the need of such a volume as the one that lies before us.

Professor Beard has done a useful piece of work. The history of our country during the years covered in this volume is mainly the record of social and economic evolution which was so rapid and powerful as to be almost a revolution. No period of equal length in our history has been fraught with events of more permanent significance than this. The author has set them forth elearly, logically and fairly. The work is intended primarily as a text-book, but all who are interested in our recent history will find it both interesting and useful.

W. J. McGLothuin.

A History of Unity Baptist Church. By Otto A. Rothert. Press of J. P. Morton \& Co., Louisville, Ky. 1914.

This brochure of 59 pages is an excellent example of a type of historical writing which must be cultivated more and more in America, that is the history of individual institutions. In this way better than in any other the inner life of the people can be understood and presented to the public. This chureh is to be congratulated in that it has found such a competent and enthusiastic historian. The life of the Church has been adequately and attractively presented.

\section{PRACTICAL THEOLOGY.}

The Church and the Kingdom: A New Testament Study, By Jesse B. Thomas, D.D., LL.D. Baptist Book Concern, Louisville, Ky., 1914. 311 pp. $\$ 1.25$, postpaid.

The venerable professor emeritus of Newton Theological Institution leaves no one to doubt that he is a Baptist. None but a Baptist could have written "The Mould of Doctrine," or "The Church and the Kingdom." The interpretation of the 